close contact between the eight departments of the Institute. An important aspect of the work is testing grass and clover strains from other latitudes both as pure stands and mixed with indigenous species. A new approach to reseeding is provided by destroying swards chemically. There are indications that different species roact differently to particular chemicals and selective killing of species may be possible in the future. The growth characters of species and varieties are being studied in field and pot oxperimonts as well as in a controlled environment. It has been shown that light breaks given to extend day-length in spring hastens ear formation in Timothy with increase in sced yield. It is now well established that increase in soil nitrogen under loy has a dominant influence on crop production. The physical condition of the soil is also improved by leys, and experiments are in progress to see how far this affects the availability of potash and phosphate. Extra-mural experiments in progross on private farms give information about grass management under a range of soil and environmental conditions. Among research projects in animal nutrition are in vitro digestibility studies on a wide range of herbages gathered at different stages of growth and the use of enzymes for digesting specific tissues such as fibre. The interaction of animal and pasture within intensive systems of husbandry is being investigated in a series of experiments. Animal agronomy is concomed, in broad aspect, with animal production in rosponse to type of sward, and management and methods of determining tho quality and amount of herbage eaten by the grazing animal are being investigated.

\section{The Wildfowl Trust, Slimbridge}

S. T. JoHNSTONE comments in the fifteenth annual report of the Wildfowl Trust that the long spell of severe weather in 1963 brought about the deaths of some 9 per cent of the total collection at Slimbridge (Pp. $150+45$ photographs. Edited by Hugh Boyd and illustrated by Peter Scott. Slimbridge: The Wildfowl Trust, 1964. $17 s .6 d$.$) . The limited heating accommodation available$ soon became crowded with the more delicate waterfowl. Those that were taken in at the start of the cold spell survived well, but those that were caught up as the Arctic conditions continued suffered heavy losses. Cuban, fulvous and red-billed whistling duck were casualties. On the other hand, Javan, spotted and white-faced whistling duck, which were given priority, came through without loss. A species which had heavy losses was the North American ruddy duck, and while there had been twelve pairs in the Rushy Pen and some odd males in the autumn, when the spring arrived these had been reduced to five females and eight males. The extreme cold delayed nesting, and the first eggs were three weeks late. Once the weather broke the breeding season reached its peak very quickly. There was a record number of birds raised - more than 1,300 at Slimbridge and 300 at Peakirk. 104 kinds nested and 96 kinds wero reared. Andean geese were reared for the first time, bringing the number of forms of waterfowl reared at Slimbridge to 123 . The collection now contains some 2,250 birds of 160 kinds and races. Unfortunately, the blackheaded duck (Heteronetta atricapilla) is no longer represented. The male, the only one in Europe, that had been at Slimbridge for five years, died during the cold weather. Interesting arrivals have been additions to the greater, Cuban and Chilean flamingos, and a male bronze-winged duck for a tame female-it is hoped that having laid eggs for the past four years, she will do so again this year and that the eggs will be fertile. One of the two female buffeheads has been exchanged for a male.

\section{World Directory of Crystallographers}

A THIRD edition of the World Directory of Crystallographers is being prepared. The editor of this edition is Dr. D. W. Smits, of Groningen, Netherlands, and biographical information is being collected for each country by a sub-editor. It is intended to include in the Directory all practising crystallographers, including graduate students. Readers in the United Kingdom who consider their names should be included in the Directory, but who have not received a questionnaire by November 30, are requested to write to Dr. P. T. Davies, Shell Research, Ltd., Thornton Research Centre, P.O. Box 1, Chester.

\section{Soils in North-west Ghana}

TECHNiCAL Roport No. 62 of the Agricultural Resoarch Institute (Ghana Academy of Sciences) is on "Soils of the Seilo-Tuni Land Planning Aroa, Wala District, Noar Wa, Upper Region" and is by H. B. Obeng. (Pp. 196+4 maps. Agricultural Research Institute, Kumasi, 1963.) 'The area in question comprises 420 square miles in the north-west of Ghana. It has a long dry season (October-April) when the water problem is acute; the average annual rainfall is 44 in., the humidity varies between wide limits, tho mean annual maximum and minimum temperatures are $98^{\circ} \mathrm{F}$ and $69^{\circ} \mathrm{F}$. Most of the area lios on Cape Coast and Dixcove granites, but Lower and Upper Birrimian rocks underlio a considerable part and there are smaller areas of mixed parent material and of Black Volta alluvium derived from the above-montioned rocks. It is probable that much of tho area has been raised and degraded several times because there are ironpan-capped remnants of peneplains and river terraces at various heights above the present flood plains. Tho topography is gently undulating with broad valleys, and the vegetation is mainly short grass savannah with scattered shrubs and trees. There is a large. variety of soils; sheet erosion is very common and between the upland concretionary soils and the valley bottom soils there are wide areas of colluvial drifts, falling within tho group of Savannah Ochrosols, providing the best soils for crops such as yams, guinea-corn, maize, beans and groundnuts. About 25 per cont of the area is considered suitable for mechanized cultivation and 40 per cent for grazing; the remainder should be reserved for woodland and water-shed protection. The bulk of the report comprises a description of the soil associations and detailed recommendations for the improvement of agricultural practices. The four maps of geology, soils and Land Capability are on a scale of approximately 1 in. to 1 mile.

\section{Priorities in the Physiology of Reproduction}

The fifth International Congress on Animal Roproduction and Artificial Insemination was held in Trento, Italy, during September 6-13. It was attended by about, 1,200 scientists from more than 60 countries, and at the closing sossion the Congress approved a memorandum setting out the problems in this field which, in the light of present knowledge, appear to call for most urgent attention, or to offer most promising investigation. Research in mammalian reproduction has two major objectives, the increase of food production on one hand and the control of population expansion on the other. Divergent as these interests are at the applied levol, both are served by basic research, much of which is also related to other aspects of physiology. Furthermore, although the control of human reproduction commands so much attention, it must not be forgotten that human infertility and fotal mortality, menstrual disordors and other gynæcological problems still call for investigation. Indeed, recent progress in these important fields has been far from spectacular, and the 'conclusions' of the congress were obviously right in displaying no complacency in this rogard. Among the more gencral themos suggested for future work, immunological aspects of reproduction, especially the antigenicity of gametes and fotal-maternal incompatibility have prior place. They constitute a rewarding field of study. Environmental influences on reproduction are still felt to be in need of elucidation, particularly in relation to the interaction of environmental and horeditary factors. Another fiold of funda- 